\title{
Plasminogen activator inhibitor-1 (PAI-1) and urokinase plasminogen activator (UPA) in sputum of allergic asthma patients
}

\author{
Krzysztof Kowal, Sebastian Żukowski, Marcin Moniuszko, \\ Anna Bodzenta-Lukaszyk
}

Department of Allergology and Internal Medicine, Medical University of Bialystok, Poland

\begin{abstract}
Urokinase plasminogen activator (uPA) and its inhibitor (PAI-1) have been associated with asthma. The aim of this study was to evaluate concentration of UPA and PAI-1 in induced sputum of house dust mite allergic asthmatics (HDMAAs). The study was performed on 19 HDM-AAs and 8 healthy nonatopic controls (HCs). Concentration of uPA and PAI1 was evaluated in induced sputum supernatants using ELISA method. In HDM-AAs the median sputum concentration of uPA (128 pg/ml; 95\% CI 99 to $183 \mathrm{pg} / \mathrm{ml})$ and PAI-1 (4063 pg/ml; 95\%CI 3319 to $4784 \mathrm{pg} / \mathrm{ml})$ were significantly greater than in HCs $(17 \mathrm{pg} / \mathrm{ml} ; 95 \%$ CI 12 to $32 \mathrm{pg} / \mathrm{ml}$; p<0.001 and $626 \mathrm{pg} / \mathrm{ml} ; 95 \%$ CI 357 to $961 \mathrm{pg} / \mathrm{ml}$; p<0.001 for uPA and PAI1 respectively). The sputum concentration of uPA correlated with sputum total cell count $(\mathrm{r}=0.781 ; \mathrm{p}=0.0001)$ and with logarithmically transformed exhaled nitric oxide concentration $(\mathrm{eNO})(\mathrm{r}=0.486 ; \mathrm{p}=0.035)$ but not with $\mathrm{FEV}_{1}$ or bronchial reactivity to histamine. On the contrary, the sputum PAI- 1 concentration correlated with $\mathrm{FEV}_{1}(\mathrm{r}=-0,718 ; \mathrm{p}=0.0005)$ and bronchial reactivity to histamine expressed as $\log _{\mathrm{PC} 20}(\mathrm{r}=-0.824 ; \mathrm{p}<0.0001)$ but did not correlate with sputum total cell count or eNO. The results of this study support previous observations linking PAI-1 with airway remodeling and uPA with cellular inflammation. Moreover, the observed effect of uPA seems to be independent of its fibrynolytic activity.
\end{abstract}

Key words: Plasminogen activator inhibitor - Asthma - Allergen challenge

\section{Introduction}

Asthma is a chronic, inflammatory disease, which is characterized by reversible bronchoconstriction associated with characteristic signs and symptoms $[1,2]$. Histopathological examination of bronchial tissue from asthmatic patients reveals destruction of airway epithelium and profound infiltrations of inflammatory cells including $\mathrm{T}$ cells, eosinophils, basophils and monocytes $[1,2]$. Even in mild, newly diagnosed asthma patients some signs of irreversible bronchial wall remodeling can be unequivocally demonstrated (3). Those irreversible changes in the airway wall consist of increased deposition of extracellular matrix (ECM) proteins, hyperplasia and hypertrophy of smooth muscle cells, mucous cell metaplasia and increased num-

Correspondence: K. Kowal, Dept. of Allergology and Internal Medicine, Medical University of Bialystok, Sklodowskiej-Curie 24a, 15-276 Bialystok, Poland; tel.: (+4885) 7468373, fax.: (+4885) 7468601, e-mail: kowalkmd@amb.edu.pl, kowalkmd@yahoo.pl ber of blood vessels [2]. Progression of these structural changes is associated with increased bronchial hyperreactivity which clinically can be demonstrated by an exaggerated response to nonspecific bronchoconstrictive stimuli such as histamine or metacholine $[4,5]$.

Urokinase-type plasminogen activator (uPA) and plasminogen activator inhibitor-1 (PAI-1) play an important role in the regulation of inflammatory response and tissue remodeling [6,7]. An important role of PAI-1 in the regulation of tissue remodeling in asthma was demonstrated in an OVA-induced murine asthma model [8]. Airways of OVA-sensitized and challenged PAI-1-/- mice were characterized by reduced collagen and fibrin deposition and increased matrix metalloproteinase-9 (MMP-9) activity in comparison with those of wild type mice. The plasminogen activator system (PAS) plays an important role in regulating ECM proteolysis, both directly through plasmin formation and indirectly through plasminmediated activation of matrix metalloproteinases 
(MMPs) [7]. Plasminogen activator inhibitor-1, the principal inhibitor of PAS in the alveolar space, has been recently involved in the pathogenesis of asthma, by inhibition of both fibrinolysis and the MMP system [9]. Plasminogen activator inhibitor-1, indeed, promotes ECM deposition in the airways of a murine model of chronic asthma [8] and its expression is increased in lung mast cells from asthmatic patients [10]. The importance of uPA in the regulation of Th-2 type immune response has been recently demonstrated using uPA deficient mice (uPA-/-). Those mice have a profound immune defect in response to an antigen eliciting Th-2-type immune response [11]. Primed and subsequently challenged with schistosomal egg antigen uPA -/- mice fail to generate $\operatorname{IgE}$ response and do not produce high level of interleukin (IL) -4, IL-5 and IL-13 [11]. Moreover, the number of inflammatory cells, including eosinophils and T lymphocytes, infiltrating pulmonary granulomas is significantly reduced indicating a failure of recruitment of those cells to the sites of Th-2 type inflammatory response [11].

Also in humans several studies demonstrated association of fibrynolytic system with asthma and bronchial hyperresponsiveness [12-17].

It was therefore of interest to evaluate the levels of locally produced UPA and PAI-1 in the airways of house dust mite allergic asthmatics (HDM-AAs) in relation to functional lung parameters and selected indices of airway inflammation.

\section{Materials and methods}

Study participants. The study was performed on 19 HDM-AAs and on 8 nonatopic healthy controls (HCs). The allergic asthmatic patients had recent episodes of dyspnea, cough and wheezing upon dust exposure and had positive skin prick test results with house dust mite allergens, significant bronchoconstrictive response to inhaled histamine and positive bronchial allergen challenge. All patients who had received allergen immunotherapy or any antiasthma medication, (with the exception of short-acting beta-agonists used as needed) before the initial visit were not included in the study. The short acting beta agonists were withdrawn at least 2 days before the study. Other exclusion criteria included respiratory tract infection within 3 months before the study, smoking, or any systemic disease.

Skin prick tests. All participants were skin tested using prick methodology with a screening panel of aeroallergens (Allergopharma, Reinbek, Germany) as described earlier [18].

Bronchial challenge. Histamine bronchial challenge was performed according to the method previously described elsewhere [18]. Briefly, all patients inhaled doubling concentrations of histamine starting from a concentration of $0.62 \mathrm{mg} / \mathrm{ml}$. Aerosol was generated using a DeVilbis \#646 nebulizer attached to a Rosenthal - French dosimeter. All subjects performed five inspiratory - capacity breaths of given histamine concentration. Forced expiratory manoeuvres were performed 90 seconds after each fifth inhalation. The procedure was continued until either at least $20 \%$ fall of $\mathrm{FEV}_{1}$ or histamine concentration $32 \mathrm{mg} / \mathrm{ml}$ was reached. Bronchial reactivity to histamine is expressed as histamine concentration causing $20 \%$ fall of $\mathrm{FEV}_{1}\left(\mathrm{PC}_{20}\right)$.
Bronchial provocation test with aqueous Dp extracts (Allergopharma, Germany) was performed according to the method previously described elsewhere [18]. In brief, increasing doses of allergen $(0.8,4,20,100,500$ and $2000 \mathrm{SBE})$ were administered using a De Vilbis \#646 nebulizer attached to a Rosenthal-French dosimeter. Forced expiratory manoeuvres were performed 15 minutes after inhalation of each dose of the allergen extract. Allergen inhalations were continued until either at least $20 \%$ fall of $\mathrm{FEV}_{1}$ or a cumulative dose $5000 \mathrm{SBE}$ was reached. Then $\mathrm{FEV}_{1}$ was measured every 15 minutes during the first hour, every 60 minutes during the next 11 hours and after 24 hours. Bronchial reactivity to $\mathrm{Dp}$ is expressed as Dp dose causing $20 \%$ fall of FEV $\left(\mathrm{PD}_{20}\right)$.

Bronchial challenge with histamine or Dp allergen extract were performed only in HDM-AAs.

Exhaled nitric oxide measurements. Concentration of nitric oxide (NO) in the expired air was evaluated "on-line" using a chemiluminescence analyzer $\mathrm{NOA}^{\mathrm{TM}} 280 \mathrm{i}$ (Sievers, USA). The measurements were performed according to ATS recommendations as described before [19]. Briefly, each patient exhaled over a $30 \mathrm{~s}$ period against the fixed expiratory resistance of $16 \mathrm{~cm} \mathrm{H}_{2} \mathrm{O}$, which resulted in a constant flow of $50 \mathrm{~mL} / \mathrm{s}$. Both $\mathrm{NO}$ concentration and flow rate were displayed on the screen. A plateau of NO concentration in the exhaled air at the selected exhalation rate was automatically selected by the computer software according to the ATS recommendations. The NO measurements were repeated 3 times and the mean value was used for analysis.

Sputum induction Sputum was induced according to the method originally described by Popov et al. [20] which we presented in details before [21]. Briefly, after premedication with $200 \mathrm{mcg}$ of inhaled salbutamol patients inhaled hypertonic saline solution ( 3 to $5 \% \mathrm{NaCl})$. The collected sputum volume was measured, mixed with an equal volume of $0.1 \%$ DTT (dithiotreitol) and than rocked at room temperature for 15 minutes. The samples were subsequently filtered through $0.42-\mu \mathrm{m}$ Millipore filter and centrifuged at $1500 \mathrm{~g}$ for 10 minutes. The supernatants were immediately aliquoted and frozen at $-70^{\circ} \mathrm{C}$ until further analysis. The pellets were resuspended in phosphate-buffered saline and total number of nonsquamous cells was assessed using Fuchs Rosenthal chamber.

Biochemical and immunologic assays. Concentration of PAI-1 and UPA antigen in the supernatants was evaluated using enzymelinked immunosorbent assays (Asserachrom, Diagnostica Stago, USA) according to the manufacturer's instruction as described before [22]. All samples were run in duplicates.

Ethical issues. The study was approved by the local Ethics Committee (R-I-003/188/2005). All participants provided written informed consent.

Statistical analysis. Continuous variables were compared using the Wilcoxon test. Multiple regression analysis was used to determine relationship between quantitative parameters. Data for continuous variables were expressed as median with $95 \%$ confidence intervals $(95 \% \mathrm{CI})$. All computations were carried out using the Statistica software.

\section{Results}

There was no difference in gender distribution and age between HDM-AAs and HC (Table 1). Patients with asthma were characterized by significantly lower lung function parameters and significantly elevated eNO (Table 1). In HDM-AAs the median sputum concentrations of uPA (128 pg/ml; 95\% CI 99 to $183 \mathrm{pg} / \mathrm{ml})$ 
Table 1. Patients characteristics.

\begin{tabular}{|l|c|c|c|}
\hline & HCs $(\mathrm{n}=8)$ & HDM-AAs $(\mathrm{n}=19)$ & HCs vs HDM-AAs \\
\hline Age (years) & $27(18-40)$ & $28(21-38)$ & $\mathrm{p}=0.595$ \\
\hline Sex $($ female/male) & $3 / 5$ & $7 / 12$ & $\mathrm{p}=0.88$ \\
\hline $\mathrm{FEV}_{1}(\%$ predicted$)$ & $108(100-120)$ & $100(91-107)$ & $\mathrm{p}=0.021$ \\
\hline $\mathrm{PC}_{20}(\mathrm{mg} / \mathrm{ml})$ & $\mathrm{ND}$ & $3.0(0.64-6.7)$ & NA \\
\hline $\mathrm{PD}_{20}(\mathrm{SBE})$ & $\mathrm{ND}$ & $1515+/-1132$ & $\mathrm{NA}$ \\
\hline Exhaled NO $(\mathrm{ppb})$ & $14(9-20)$ & $106(62-233)$ & $\mathrm{p}=0.0001$ \\
\hline Sputum cell count $\left(\mathrm{cells} \times 10^{6} / \mathrm{ml}\right)$ & $1.6(0.85-3.66)$ & $5.04(3.15-6.13)$ & $\mathrm{p}=0.0007$ \\
\hline $\mathrm{uPA}(\mathrm{pg} / \mathrm{ml})$ & $17(12-32)$ & $128(99-183)$ & $\mathrm{p}=0.0001$ \\
\hline PAI- $1(\mathrm{pg} / \mathrm{ml})$ & $626(357-961)$ & $4063(3319-4784)$ & $\mathrm{p}=0.0001$ \\
\hline
\end{tabular}

and PAI-1 (4063 pg/ml; 95\% CI 3319 to $4784 \mathrm{pg} / \mathrm{ml}$ ) were significantly greater than in $\mathrm{HCs}(17 \mathrm{pg} / \mathrm{ml} ; 95 \%$ CI 12 to $32 \mathrm{pg} / \mathrm{ml} ; \mathrm{p}<0.001$ and $626 \mathrm{pg} / \mathrm{ml} ; 95 \%$ CI 357 to $961 \mathrm{pg} / \mathrm{ml} ; \mathrm{p}<0.001$, for $\mathrm{UPA}$ and PAI-1 respectively) (Table 1). Analysis of functional and immunologic parameters revealed that sputum PAI-1 concentration correlated with baseline $\mathrm{FEV}_{1}(\mathrm{r}=-0,718$; $\mathrm{p}=0.0005$ ) and with bronchial reactivity expressed as $\log _{\mathrm{PC} 20}(\mathrm{r}=-0.824 ; \mathrm{p}<0.0001)$ (Fig. 1). On the contrary sputum concentration of UPA did not correlate with lung function test results but was positively correlated with the number of inflammatory (nonsquamous) cells in induced sputum $(\mathrm{r}=0.781 ; \mathrm{p}=0.0001)$ and with $\log _{\text {eNO }}(r=0.486 ; p=0.035)$. No correlation of sputum PAI-1 concentration with the number of inflammatory cells or with eNO was demonstrated.

\section{Discussion}

Our study demonstrates elevated levels of uPA and PAI-1 in the airways of asthmatic patients suggesting increased local activation of the PAS in vivo. This is consistent with previous studies performed in humans and in animals [6-17]. However, activation of the PAS is not associated exclusively with asthma but its activation could also be demonstrated in other inflammatory lung diseases such as chronic obstructive pulmonary diseases or cystic fibrosis [23]. The intriguing finding in this study is association of uPA and PAI-1 with different aspects of asthmatic phenotype. Concentration of uPA in sputum correlated with indices of airway inflammation, such as sputum cell number or exhaled nitric oxide concentration, while sputum PAI1 concentration was linked with indices of airway remodeling such as baseline $\mathrm{FEV}_{1}$ or $\mathrm{PC}_{20}$. Our findings in asthmatic patients are supported by results of several studies in which PAI-1-/- or UPA-/- mice were evaluated in different experimental models. In a chronic asthma model, PAI-1-/- mice were protected from increased airway remodeling in response to allergen challenge [8]. Chronic exposure to ovalbumin resulted in significantly less collagen and fibrin deposition in the airways of PAI-1-/- mice when compared with wild type mice [8]. Interestingly, however, there was no significant difference between the number of inflammatory cells infiltrating airway tissues when PAI-1-/- mice were compared with wild type mice. Similar results were obtained in a model of bleomycininduced lung fibrosis [24]. No significant change in the inflammatory cell content could be demonstrated in bleomycin-challenged wild type and PAI-1-/- mice, however in the latter animals significant reduction of lung fibrosis was seen [24]. Those experiments indicate that endogenous PAI-1 exerted little effect on cell influx to the sites of tissue injury and inflammation but significantly affects lung remodeling.

We have been already able to demonstrate that in asthmatic patients plasma PAI-1 concentration correlates with baseline $\mathrm{FEV}_{1}$ and bronchial response to histamine, but it does not correlate with peripheral blood eosinophilia or response to allergen challenge $[15,22]$. Moreover, in asthmatic patients the $-6754 \mathrm{G}$ allele of PAI-1 gene, which is a major genetic determinant of increased PAI-1 synthesis, is associated with lower baseline lung function and greater bronchial reactivity to histamine, suggesting that propensity for increased PAI-1 production is linked with bronchial remodeling [15]. Furthermore, exposure to an allergen, which leads to increased non-specific bronchial reactivity, induces PAI-1 synthesis [22]. However, no direct correlation between the increase in plasma PAI1 concentration and the provocative dose of an allergen could be demonstrated, indicating that plasma PAI-1 levels are not directly affected by allergen exposure. It seems, that the relation between the intensity of the airway inflammation and PAI-1 synthesis is complex. This assumption is supported by our current findings which show no correlation between sputum 
a. $\mathrm{R}=-0,718 ; \mathrm{p}=0.0005$

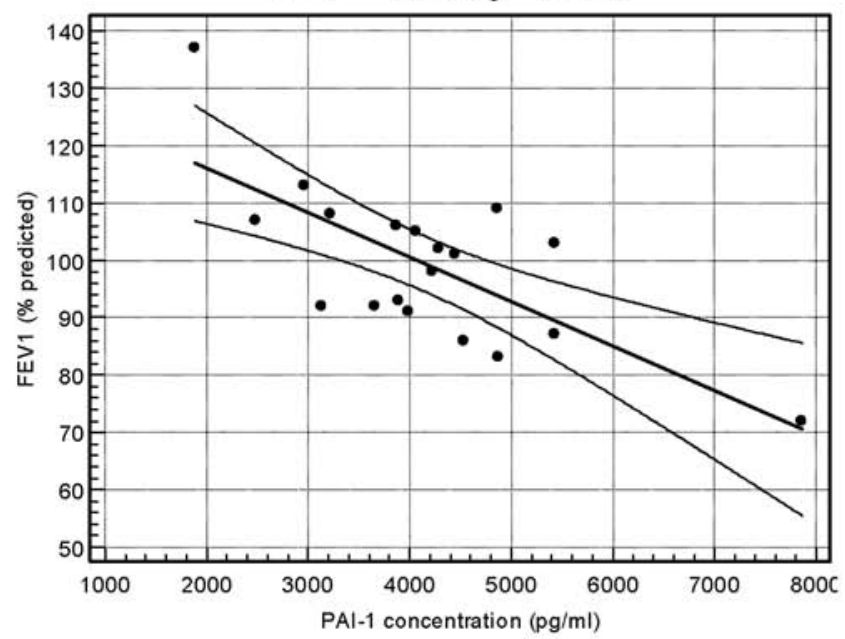

b. $\mathrm{R}=-0.088, \mathrm{p}=0.721$

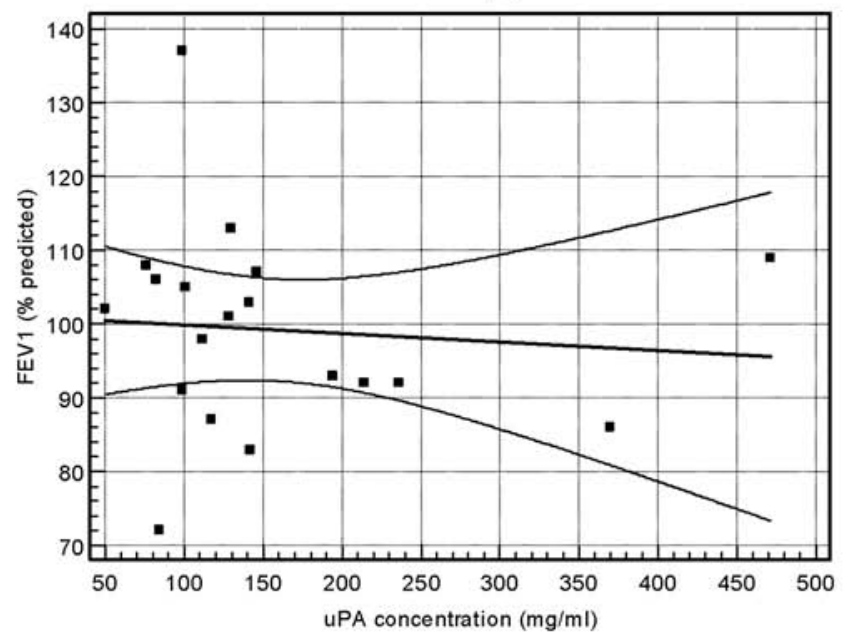

c. $R=-0.824 ; \mathrm{p}<0.0001$

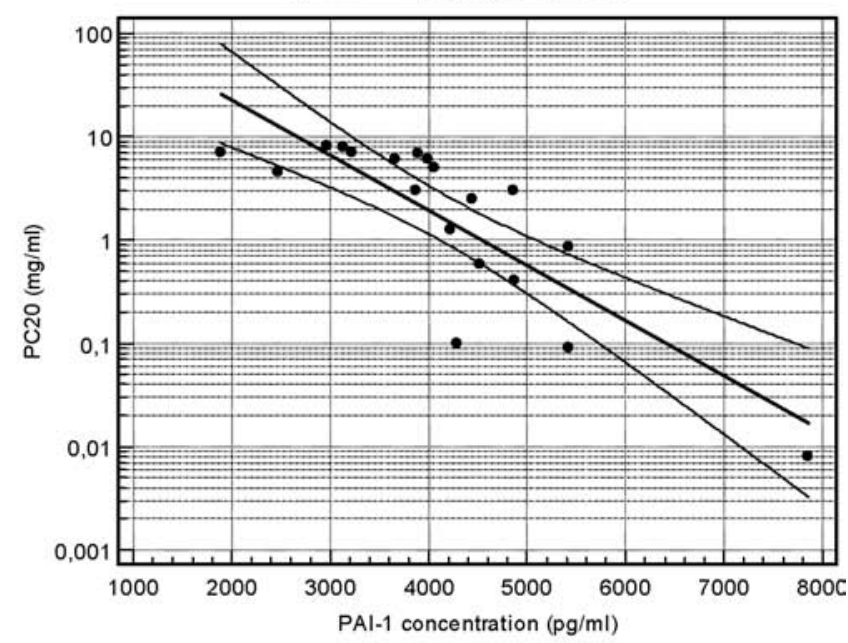

d. $R=0.153 ; p=0.532$

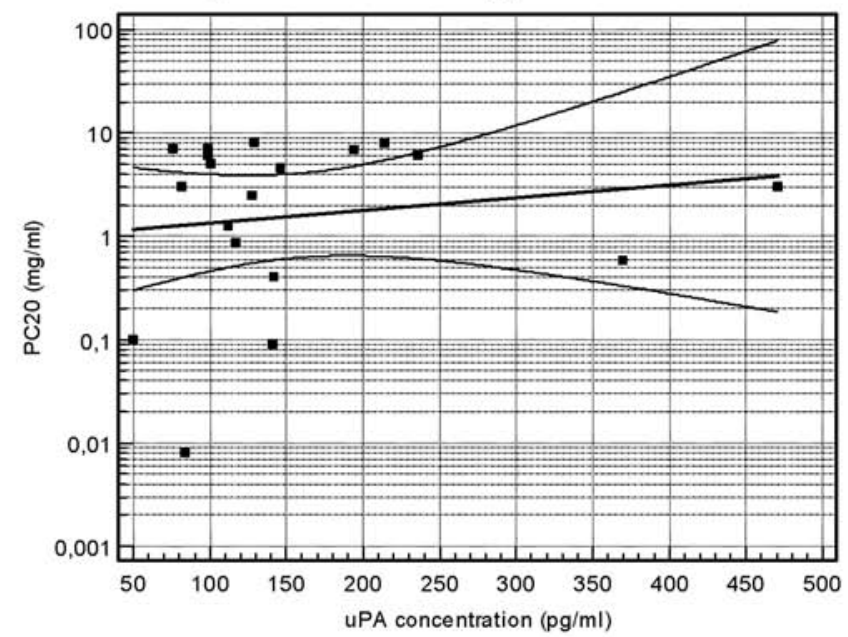

Fig. 1. Correlations between sputum uPA or PAI-1 concentration and selected parameters of lung function or airway inflammation indices in HDM-AAs (a to $\mathbf{h})$. $\mathrm{FEV}_{1}$ - forced expiratory volume exhaled during the first second. $\mathrm{PC}_{20}$ - provocative concentration of histamine which caused $20 \%$ fall of $\mathrm{FEV}_{1}$. (a,b,c,d, - page XX, e,f,g,h - page XX).

PAI-1 level and indices of airway inflammation in allergic asthmatic patients. The indices of airway inflammation, however, correlated with sputum uPA concentration suggesting more direct association. In a model of Th-2 type immune response, strong effect of uPA on cell migration has been demonstrated $[11,25]$ The effect has been demonstrated both in vitro using eosinophil adhesion assay and in vivo utilizing uPA-/mice $[11,25]$. In comparison with wild type animals, in uPA-/- mice administration of a schistosomal egg antigen, which evokes Th-2 type immune response, resulted in significantly reduced influx of inflammatory cells to the sites of antigen challenge [11]. One of the possible mechanism responsible for the reduced influx of eosinophils and $\mathrm{T}$ cells to the inflammatory tissues is decreased adhesion and migration of those cells in response to chemoattractants [25]. In fact in vitro studies demonstrated that, exogenous uPA enhanced eosinophil adhesion to ICAM-1 or VCAM-1 even in the absence of any other agonists [25]. Moreover, this effect was also observed in those cells which migrate to the airways in response to allergen challenge [25]. This phenomenon was dependent on uPA interaction with uPAR, but was independent of uPA fibrynolytic activity [25].

In summary, our study indicates that PAS is activated in the airways of asthmatic subjects. Inhibitory effect of PAI-1 is predominantly associated with tissue remodeling, while uPA is linked with intensity of airway inflammation. Further studies are necessary to elucidate the exact mechanisms responsible for the effect of PAS on development of asthma.

Acknowledgments: This work was supported by a grant from Medical University of Bialystok research grants 3-35493 (KK and AB-L). 
e. $R=0.006 ; p=0.981$

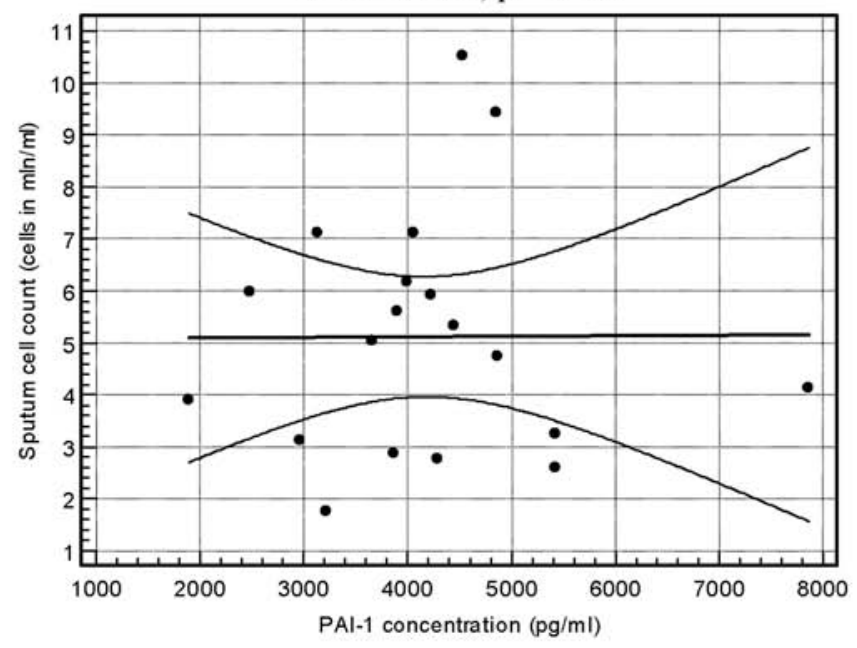

f. $R=0.781 ; p=0.0001$

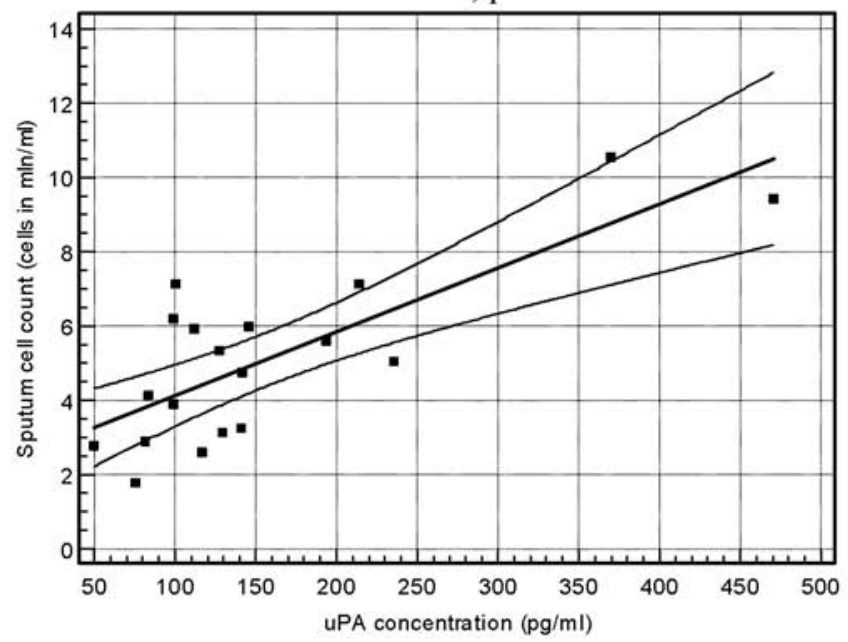

\section{References}

[ 1] Amin K, Ludviksdottir D, Janson C, Nettelbladt O, Bjornsson $\mathrm{E}$ et al. Inflammation and structural changes in the airways of patients with atopic and nonatopic asthma. Am J Respir Crit Care Med. 2000;162:2295-2301.

[2] Busse W, Elias J, Sheppard D, Banks-Schelegel A. Airway remodeling and repair. Am J Respir Crit Care Med. 1999;160:1035-42.

[ 3] Laitinen LA, Laitinen A, Haahtela T. Airway mucosal inflammation even in patients with newly diagnosed asthma. Am Rev Respir Dis. 1993;147:697-704.

[4] Jeffery PK, Wardlaw AJ, Nelson FC, Collins JV, Kay AB. Bronchial biopsies in asthma: an ultrastructural, quantitative study and correlation with hyper reactivity. Am Rev Respir Dis. 1989;140:1745-53.

[ 5] Chetta A, Foresi A, Del Donno M, Bertorelli G, Pesci A, Olivieri D. Airway remodeling is a distinctive feature of asthma and is related to severity of asthma. Chest. 1997;111:852-857.

[ 6] Binder BR, Christ G, Gruber F, Grubic N, Hufnagl P, Krebs $\mathrm{M}$ et al. Plasminogen activator inhibitor 1: Physiological and pathophysiological roles. News Physiol Sci. 2002;17:56-61.

[ 7] Kucharewicz I, Kowal K, Buczko W, Bodzenta-Lukaszyk A. The plasmin system in airway remodeling. Thromb Res. 2003;112:1-7.

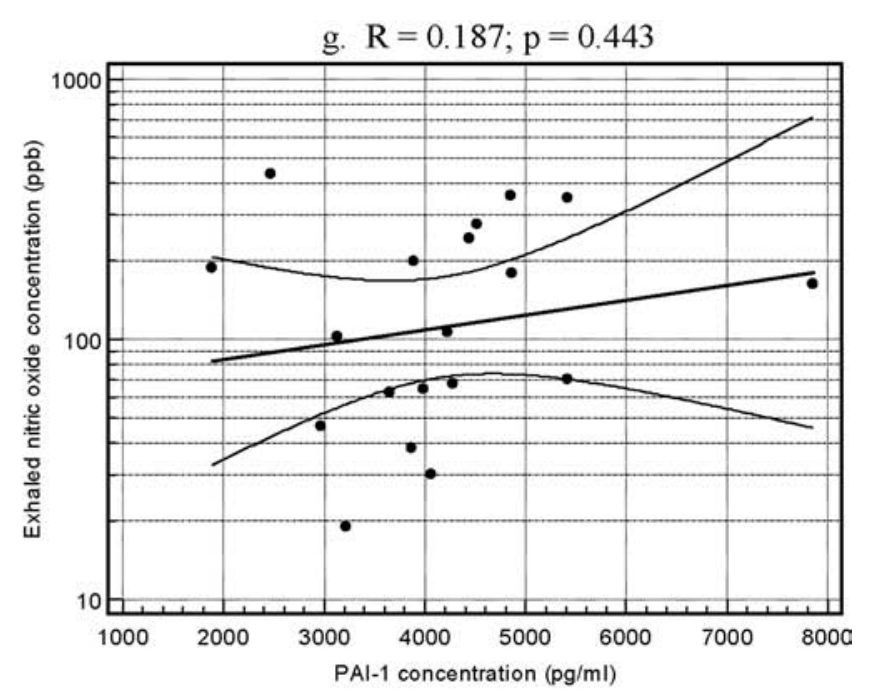

h. $R=0.486 ; p=0.035$

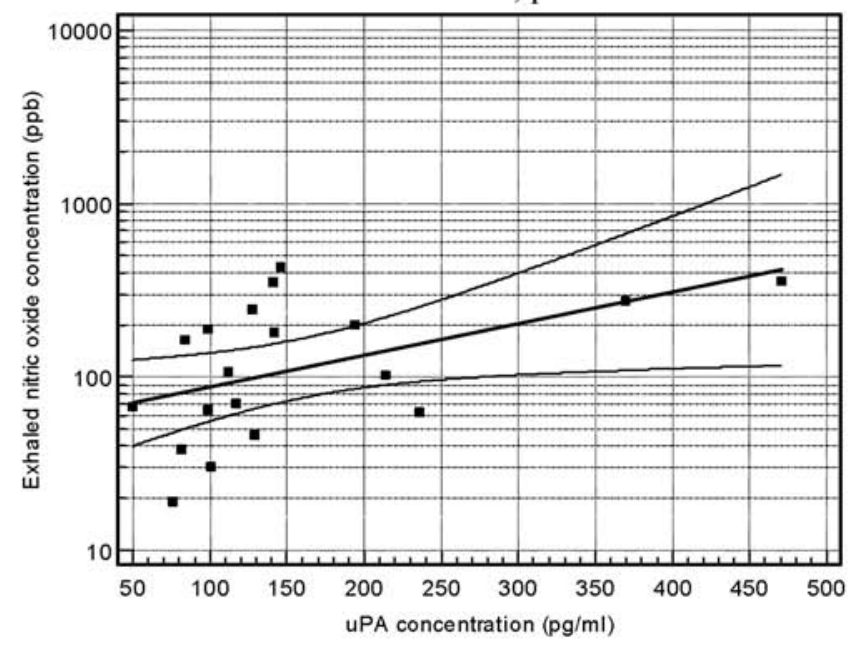

[ 8] Oh CK, Ariue B, Alban RF, Shaw B, Cho SH. PAI-1 promotes extracellular matrix deposition in the airways of a murine asthma model. Biochem Biophys Res Commun. 2002;294:1155-60.

[ 9] Cho SH, Ryu CH, Oh CK. Plasminogen activator inhibitor-1 in the pathogenesis of asthma. Exp Biol Med (Maywood). 2004;229:138-46.

[10] Cho SH, Tam SW, Demissie-Sanders S, Filler SA, Oh CK. Production of plasminogen activator inhibitor-1 by human mast cells and its possible role in asthma. J Immunol. 2000; 165:3154-61.

[11] Gyetko MR, Sud S, Chensue SW. Urokinase-deficient mice fail to generate a type 2 immune response following Schistosomal antigen challenge. Infect Immun. 2004;72:461-7.

[12] Banach-Wawrzeńczyk E, Dziedziczko A, Rość D. Fibrynolysis system in patients with bronchial asthma. Med Sci Monit. 2000;6:103-7.

[13] Banach-Wawrzeńczyk E, Dziedziczko A, Rość D Fibrynolytic system in bronchial asthma after prednisone treatment. Pol Merk Lek. 2000;7:9-11.

[14] Cho SH, Hall IP, Wheatley A, Dewar J, Abraha D, Del Mundo $\mathrm{J}$ et al. Possible role of the $4 \mathrm{G} / 5 \mathrm{G}$ polymorphism of the plasminogen activator inhibitor 1 gene in the development of asthma. J Allergy Clin Immunol. 2001;108:212-14. 
[15] Pampuch A, Kowal K, Bodzenta-Lukaszyk A, Di Castelnuovo A, Chyczewski L, Donati MB, Iacoviello L. The -675 $4 \mathrm{G} / 5 \mathrm{G}$ plasminogen activator inhibitor-1 promoter polymorphism in house dust mite-sensitive allergic asthma patients. Allergy. 2006;61:234-8.

[16] Kowal K, Bodzenta-Lukaszyk A, Pampuch A, Szmitkowski $\mathrm{M}$, Zukowski S et al. The $-6754 \mathrm{G} / 5 \mathrm{G}$ plasminogen activator inhibitor -1 (PAI-1) and C-159T CD14 polymorphisms in house dust mite allergic asthma patients. $J$ Invest Allergol Clin Immunol. 2008;18:in press.

[17] Begin P, Tremblay K, Daley D, Lamire M, Claveau S et al. Association of urokinase-type plasminogen activator with asthma and atopy. Am J Respr Crit Care Med. 2007;175: 1109-16.

[18] Kowal K, Osada J, Zukowski S, Dabrowska M, DuBuske LM, Bodzenta-Lukaszyk A. Expression of interleukin-4 receptor in bronchial asthma patients treated with specific immunotherapy (SIT). Ann Allergy Asthma Immunol. 2004; 93:68-75.

[19] Kowal K, Moller HJ, DuBuske LM, Moestrup SK, BodzentaLukaszyk A. Differential expression of monocyte CD163 in single- and dual-asthmatic responders during allergeninduced bronchoconstriction. Clin Exp Allergy. 2006;36: 1584-91.

[20] Popov TA, Pizzichini MMM, Pizzichini E, Kolendowicz R, Punthakee Z, Dolovich J, Hargreave FE. Some technical fac- tors influencing the induction of sputum for cell analysis. Eur Respir J. 1995;8:559-565.

[21] Moniuszko M, Bodzenta-Lukaszyk A, Kowal K, Dabrowska M. Bronchial macrophages in asthmatics reveal decreased CD16 expression and substantial levels of receptors for IL-10 but not IL-4 and IL-7. Folia Histochem Cytobiol. 2007;45: 181-9.

[22] Kowal K, Bodzenta-Lukaszyk A, Pampuch A, Szmitowski M, Donati MB, Iacoviello L. Plasminogen activator inhibitor-1 plasma concentration in allergic asthma patients during alergen challenge. Int Arch Allergy Immunol. 2007;144:240-6.

[23] Ciao W, Hsu YP, Ishizaka A, Kirikae, Moss RB. Sputum cathelicidin, urokinase plasminogen system components and cytokine discriminate cystic fibrosis, COPD and asthma inflammation. Chest. 2005;128:2316-26.

[24] Hattori N, Degen JL, Sisson TH, Liu H, Moore BB et al. Bleomycin-induced pulmonary fibrosis in fibrinogen-null mice. J Clin Invest. 2000;106:1341-50.

[25] Brooks AM, Bates ME, Vrtis RF, Jarjour NN, Bertics PJ, Sedgwick JB. Urokinase-type plasminogen activator modulates airway eosinophil adhesion in asthma. Am J Respir Cell Mol Biol. 2006;35:503-11.

Submitted: 14 December, 2007 Accepted after reviews: 17 January, 2008 